\title{
Investigating the Trends of Teaching Reading Comprehension Skills at Primary Schools
}

Fisseha Motuma $(\mathrm{PhD})^{*}$

\section{Abstract}

This study explored the lived professional and academic experiences of primary school teachers in teaching reading comprehension skills. It attempted to find out whether primary school English teachers were aware of different thinking and comprehension strategies like cognitive, metacognitive and comprehension strategies:(predicting (previewing), visualizing (creating mental images), making connections (localizing), and summarizing (retelling). The study was qualitative in its approach and employed interpretive paradigm. Purposive sampling technique was employed to specify the participants. To collect the required data, focus group discussion and classroom observation were used. Accordingly, seven experienced primary school English teachers were involved in the study: two of the teachers participated in the classroom observations, whereas the remaining five teachers participated in the Focus Group Discussion (FGD). The data collected through FGD were audio-recorded and later transcribed for analysis. The collected data were analyzed based on grounded theory using open, selective and substantiate coding. The results of both the classroom observations and FGD analysis indicated that teachers gave little attention to thinking or thought-based teaching of reading comprehension. Rather, they tended to create their own culture of teaching reading: there was a high tendency to use more of teacher-led loud reading practice followed by random or mass answering of comprehension questions.

Key words: Teaching trends, reading comprehension strategies, higher-order thinking, primary school

\footnotetext{
* Assist. Professor of ELT; Dean, Faculty of Languages and Humanities Kotebe University of Education, Addis Ababa, Ethiopia
} 


\section{Background of the Study}

These days, more than ever, many agree that primary age students tend to show little interest and attention to reading. The reasons could be attributed to partly the availability of more access to technological related media (e.g. cell phone, TV, computer games), or partly because young children may not be exposed to systematic approaches or the use of strategies that could simplify text comprehension skills.

Still, it could be possible that students may spend more classroom time on learning separated words/ phrases/ sentences or on simple memory practices which may not challenge their thinking skills. And so, instead of encouraging students to think critically and construct meaning from a reading text, such situations could sidetrack them from developing reading habits.

The researcher paid pre-research visits to different primary schools in Addis Ababa, Ethiopia and observed the trends of teaching reading comprehension skills at primary school. It is felt that little concern is given to comprehension strategies and higher order thinking skills activities. Apparently, more time was spent on oral reading practices and on encouraging students to do questions of factual information taken from the reading text. What is more, it was observed that little or no attention was given to teaching reading using the strategic reading processes. Seemingly, the primary activity of students in a reading class was partly trying to read a text as fluently as possible and partly trying to comprehend the literal meaning of the text they read to answer the passage questions.

Though the ultimate goal of teaching English beginning from the early grades is to help children develop the basic English skills, different research findings indicate that a considerable number of students strive hard to read and comprehend a text effectively. The Ethiopian Ministry of Education in collaboration with an International NGOs- Research Triangle Institute (RTI), for example, conducted an early grade reading assessment in 2010 . The result shows that $80 \%$ of

children are not reading at the MOEs expected rate of reading fluency (FDRE, Ministry of Education, 2016).

Again, the result of the percentage of early grade students' reading comprehension achievement was really shocking. As reported by Smith, Stone \& Comings (2012) "the percentage for grade 2 
students who scored zero ranged from $72 \%$ in Sidama to $24 \%$ in Addis Ababa. Among grade 3 students, it ranged from $61.8 \%$ to $9.7 \%$ respectively" (p. 8)

Likewise, the findings of a research carried out by Solomon (2012) unveil that $28 \%$ of students at grade 4 found to be "non-readers" and about 58\% of students were reported as slow readers. Again, the finding presented that about $42 \%$ of the students scored below average level in the reading comprehension test.

Correspondingly, a research conducted by McCormac (2012), on the current state of early literacy development in Ethiopia has indicated that "Many children are unable to read a single word, even after grade 3. Even fewer comprehend what they read." (p. 174). She further points out that even Addis Ababa though highest scoring region in the country, suffers a lot to get children attain the expected reading achievement goals.

What is more, little is known whether teachers are using strategic approaches to teaching reading, and whether they are using comprehension activities which could improve students thinking skills. Rand Research Study Group (2002), for example, comment that though different research findings approve specific strategies that improve students' reading comprehension skills," little evidence exists about whether teachers use identified research-based strategies when teaching." (p. 31). Another significant motive to conduct this research was that many of the studies focusing on comprehension strategies and instructions has been very much limited to upper grade schools and universities (Pressley et al., 1991).

To this end, as stated by Block, Gambrell \& Pressley (2002), if children cannot decode and comprehend at the same time, it is no use continuing teaching them in the same way. So, researchers should find out alternative approaches that could improve children's comprehension skills. The central point to be underlined, according to Gravie (1990: 45), is: "Teaching students how to use strategies effectively should be the primary concern in the English classroom."

\section{Purpose of the Study}

The core purposes of this study were to study whether teachers were aware of the research-based strategies that simplify students' comprehension and higher-order thinking skills. The second focus was to find out teachers' trend of teaching reading comprehension and the types of strategies they used to facilitate students' comprehension skills. The study was also meant to 
explore teachers' lived experiences of the kinds of comprehension activities they thought could promote students' higher order thinking skills.

\section{Basic Literature Review}

As described by Block \& Israel (2005), comprehension strategies are 'mental processes' that effective readers practise to make sense of the meaning of a text. They are the techniques that effective readers use to ensure their understanding of the content of a text they read. In this sense, Anderson (1991) has described comprehension strategies as: "deliberate cognitive steps that learners can take to assist in acquiring, storing and retrieving new information” (p. 460).

For Yang (2006), "Since reading is a meaning making task, the conscious actions taken by readers to enhance understanding of the text refers as reading strategies. ”(p. 338). As noted by NSW Department of Education and Training Literacy Continuum (2010; 4), "Comprehension strategies are cognitive and metacognitive strategies readers use to accomplish the goal of comprehension."

There are two core points regarding the teaching and learning of comprehension strategies. The first is good readers should use comprehension strategies to effectively comprehend what they read. The second is teachers should teach comprehension strategies explicitly and gradually let the students use the strategies independently of the teacher. It is because“...reading comprehension is an essential component of lifelong learning. Individuals who experience difficulties reading and understanding information presented to them tend to suffer from problems in school, in the workplace, and in their communities." (Van de Broek, et al (2009: 107).

However, Mcknown \& Barnett (2007) have stated: 'Research has shown that teachers spend very little time teaching comprehension strategies.' (p. 14). Instead, teachers often focus on encouraging students doing textual questions and giving related instructions (Block \& Israel, 2005). Due to this, students might be given little time to think and process the what, how and why of what they have read.

Durkin (1978-1979) observed reading lessons in fourth grade for a year. She stated that fourth grade is the critical moment in a student's reading skills because it is the transition period from 'learning to read to reading to learn.' In her classroom observation, she found that teachers used 
very limited comprehension instructions and strategies. They rather, spent much of the classroom reading sessions on activities related to the content of the reading text. According to her finding, of the 75 hours of reading lessons she had observed, teachers used only 20 minutes (i.e. 1 percent) of the total time to teach students how to comprehend and extract new ideas from texts.

Santa (2000) argues that the work of Durkin's and the other scholars of the then time initiated many researchers to pay great interest to studying ways to help students learn and use different strategies to comprehend a text effectively. As to Santa, many of the individual focused comprehension strategy studies were found to be very successful. And this success inspired many researchers to focus their researches on using multiple strategies to promote students' reading comprehension skills. For instance, Pearson \& Gallagher (1983) emphasized that teachers should use different cognitive strategies in the process of teaching reading skills. Later, Tierney \& Cunningham (1984) subdivided the suggested cognitive strategies into pre-reading, while-reading and post-reading activities.

As stated by Santa (2000), a study conducted by Palincsar \& Brown (1984) came up with one of the most influential results in teaching comprehension strategies. The researchers planned to employ four cognitive strategies to improve students' reading comprehension skills. They did the practice first, by getting teachers to model the strategies step-by-step using the three phases of teaching reading. Then, the teachers gradually transferred the responsibility of using the strategies to the students. Accordingly, they introduced a method called reciprocal teaching of comprehension in which the teacher gradually hands over the responsibility of using comprehension strategies to the students. The result displayed that students who practised the focused comprehension strategies achieved significant progress in different comprehension measures.

Gill (2008) has commented that in teaching reading at early grade, comprehension strategies that develop higher order thinking skills should be explicitly taught. As children gain experience in using a variety of comprehension strategies, they know when and why to use a certain type of strategy. In addition, children need to be taught that reading is a process that involves different stages of practices. In other words, effective comprehension involves systematic and strategic reading processes such as pre-reading, while-reading and post-reading activities. And these are activities which promote higher order thinking skills (Mcknown \& Barnett, 2007). 
According to Ontario Ministry of Education (2003), the very purpose of reading should be developing children's thinking skills. Reading should primarily initiate children's ability to exercise higher order thinking skills. Thus,

The development of higher order thinking skills is essential throughout the primary grades. In the early stages of reading development, higher order thinking can be developed at the oral level through teacher read-alouds and shared reading. In the reading-to-learn stage, classroom teachers need to ask questions that challenge them to move beyond what they recall of the text on to what they understand through application, analysis, synthesis and evaluation (pp. 20-21).

Accordingly, it is believed that the approach stated above could provide children with the opportunity to develop better comprehension skills. Children can develop higher order thinking skills through shared reading approach which they could construct and verbalize own opinions and demonstrate their thinking skills.

Tierney \& Cunningham (1984) have presented detailed description on the concept of strategic reading processes. Their ideas can be reviewed as follows: Of all, it should be stressed that reading should start from where the students are. It should first begin by encouraging the students to explore their own learning potential and already existing knowledge of a topic of reading. Sated differently, the strategy to be used before reading should enable the students to activate their own related schematic knowledge of the topic. They should exercise predicting what the content of the text would be by looking at the topic, related pictures, diagrams, title heading, etc. The predicting strategy used at this stage enhances the children's ability to become more aware of self-understanding of the topic before they start reading.

As they begin reading, the strategy to be used should give the students the opportunity to visualize what the text represents by creating images of the things or events described in the reading text. What is more, the strategies students use before and during reading should have a positive effect on their understanding of the text. That is to say, students should be able to identify some important points (main ideas) and then be able to summarize the text content in their own language. Yet again, once they complete reading, they should practise making connections between the text message and the reality in their actual situation. 
Cognitive researchers claim that a reader should use his or her mind to extract the expected meaning from a reading text. What is quite interesting is the belief that meaning is not just contained in the words on a page. Instead, the reader tries to construct the meaning through the process of interacting and interpreting the text message (Van de Broek, P. et al. 2009). A reader does this by brainstorming his/her own prior knowledge and experience of the topic. The core point is the success of a reader in constructing meaning largely depends on the reader's metacognitive ability (i.e. the reader's ability to think about and process ideas).

Conversely, the traditional view of reading was coined from the behavioralist theory of learning. It emphasizes that students should be encouraged to mechanically decode facts of the content of a reading text and try to comprehend the message through rote memorization. Yet, the contemporary approach called the cognitive theory of reading emphasizes that students should learn how to use cognitive comprehension strategies to construct meaning from a text.

The point of departure is that the behavioralists are in favor of mastery of facts in a text, whereas for the cognitivists, reading is a cognitive (mental) process which involves comprehension strategies. In the behavioralists view, a reader is seen as a passive receiver, while the cognitivists consider a reader as an active comprehension strategy user.

\section{Methodology}

This research used qualitative method of data description. The study employed purposive sampling technique in which it involved seven English teachers as study participants in the academic year 2021. It involved two of the study participants in classroom observation while the remaining five teachers participated in FGD.

In order to gather the required data, two classroom observations and FGD were used as source of data collection and analysis. The FGD was carried out on semi-structured items. It contained eight open-ended questions to probe the participants' conception, knowledge and experiences on the topic and, secondly, to allow the participants to be flexible in the way they gave responses in the process of the discussion. The FGD was audio-recorded and then transcribed for analysis. The data were analysed using open, selective and substantiate coding based on grounded theory. 


\section{Discussion of Data}

\section{Classroom Observation Report I}

School Name: Primary School A

Date: $12 / 5 / 2021$

Grade: 4

Section: $D$

Regular Teacher: 1

Observer: FM

I conducted the observation on Tuesday morning, $3^{\text {rd }}$ May, 2021. I observed a reading class at a Primary School, grade 4, and section D, in Addis Ababa, Ethiopia. I first contacted the teacher at their lounge and explained the purpose of my research. I informed her that I was conducting a mini research on the topic: trends of teaching reading comprehension skills at primary schools. I assured her that the observation had nothing to do with her performance. I also promised her to keep her name confidential. Anyway, after almost having a sort of debate, she finally let me observe her class.

\section{Let me first tried to describe the class:}

The school is in a suburb of Addis Ababa, at Akaki-Kality sub-city. It is located in a highly, densely populated area. The residences are believed to be at a low or medium socio-economic status. The class as I mentioned earlier was grade 4 section D. The room was a moderate size, but it was getting older. It was a bit stuffed, accommodating 56 students and so, the class was somewhat congested and noisy. Some of the windows were dirty and some others left open with missing glasses. There were twenty wooden desks in a row of four lines.

The blackboard was rectangular in shape and small in size with two holes; one on the top left corner and the other hole was nearer to the middle of the board. It, too, was faded out and untidy. The wall was older and painted grey. It appeared rough with a lot of scratches scattered across the wall. The ceiling of the room was painted white but with lots of scattered cracks and dirty spots formed due to drops of rain leakages. There was no table for the teacher. But, there was a chair with one leg skewed out to the back. 
In general, the classroom of grade 4 section D appeared inconvenient for teaching children. Seemingly, it was really boring even for adults let alone for children to sit and learn in such jammed and spotty classroom.

The class was conducted from 8:30 am-9:15am. Before going into detail observation of the class, I requested the teacher to show me her lesson plan. For this particular class period, her goals were stated as: students read a passage and do passage questions in a group. The second which reads: Students model teacher's pronunciation and read aloud turn by turn. Seemingly, she attempted to improve her students' reading pronunciation and a sort of reading fluency. It also appeared that she tried to focus on students' 'reading correctly or a sort of accuracy in pronunciation.

As for the design and activities of the lesson, the teacher included teacher activities such as presenting the lesson, reading aloud to the class, asking questions, and giving support while students read. On the other hand, students' activities were listed as: listening, reading to the class, doing passage questions in group, answering questions and actively participate in classroom discussion.

The teacher started the lesson late. She wasted 6 minutes. Then, within the first five minutes of class, students were asked to show their homework to the teacher while the teacher tried to move in and attempted to simply have a look at the students' exercise book. The class was a bit noisy and some students were chatting and some others were even having private discussions.

Then, the teacher told the students to open their textbook on page 129. The day's reading lesson was titled: 'Lalise's First Bus Journey-Part One'. She tried to make sure that all the students opened their textbook on the right page. Next, she told all the students to be silent and follow her while she was reading out loud to the class. She read the passage twice, and then called on a student, called Gosa, who, presumably, became 'good reader', to read aloud to the class. Others were told to listen quietly. While the student was reading, the teacher was intermittently stopping the student to correct his word pronunciation. Next, she called on a student called, Mitin (a girl), to read. Teacher gave similar correction as she did for the former. 
After that she told the class to try to read in the same way at their home. In class, she told the students to be in a small group of three or four. She told them to work in their group and answer the comprehension questions. While doing in group, the class was really noisy and students were openly talking mainly in their mother tongue. There were even some students who were indifferent in all what was going on in the class. I even saw some two students who changed their seat without the knowledge of the teacher. Yet, when the teacher saw a student behaving differently or misbehaving, she often frowned at the student or gave finger warning. In some cases, she appeared offensive towards some students who repeatedly disturb her.

After the students "discussed" the passage questions, the teacher tried to create a whole class discussion. The class tried to review the answers for the questions. The teacher read a question and the students raised their hands and gave answers to the questions. But, if a student gave wrong answer, the teacher echoed the answer to the class and asked for confirmation. Finally, when the teacher got correct answer for the question she asked, she encouraged the class to say the answer together. More or less, it was more of a teacher-centered classroom, but included some elements of student involvement to some extent.

Pedagogically, the teacher mainly used questioning and answering strategy to facilitate learning. She tended to translate some words or messages, and in some cases, she used students' first language directly during presentation and in some cases, during discussion. She spent almost twenty-five minutes on reading and doing passage questions.

In this class, what I really liked which I think also kept the students at ease and made them less anxious, was that the teacher was serious about group work. In addition, she was also telling the students that they should make a lot of practice with reading to improve their reading skills. However, the teacher did not inform the students any comprehension strategies to use for reading. And even to anyone's surprise, the students were not well communicated the purpose why they were to read the passage.

Apparently, there was no fair balance between teacher and student talks. Most often, the teacher spent much time on correcting students' errors, giving simple instructions and reading questions to the class. As it was briefly mentioned above, I had noticed early that it was more of teacher- 
centered but included a little learner-centered activity like group work and individual answers during whole class discussion.

Finally, the teacher ended the class after she informed the homework activity for the next period. However, there was no lesson summary, and no attempt to check what the students really comprehend from the day's reading passage. Again, there was no attempt to invite students to reflect on what they had learned from "Lalise's First Bus Journey".

After my observation, I asked the teacher a few questions. I wanted to learn more about her understanding of reading comprehension skills. She mainly thought that reading is an oral practice where teacher read out loud to the students and students modeled teacher's way of reading. The core purpose of reading passage was, as to the teacher, reading a passage with good pronunciation, fluency (or speed) and answering passage questions.

In addition, I asked her about her students' background in English. She commented that her students had very poor English experience. As to the teacher, her students wanted her to translate some instructions and messages into their mother tongue. Overall, she was not happy with the lesson. She felt that teaching reading was difficult because, as to the teacher, students had low reading and understanding ability. Again, the teacher herself confessed that she did not have the necessary pedagogical skills to teach reading.

\section{Classroom Observation Report II}

School Name: Primary School B

Date: $13 / 5 / 2021$

Grade: 5

Section: A

Regular Teacher: 2

Observer: $F M$

The second class I observed was grade 5 section A of the same school. The classroom was in a newly built building and so a bit better than the previous class I observed. The room was of good size to accommodate about 50-60 students. The desks appeared new and relatively comfortable 
for the learners. The well was painted grey and was in a good condition. There was a table and a chair for a teacher. The blackboard was also more or less appropriate to the standard of the room.

The room had a metal door of double openings and appeared fairly new. One side of the wall was totally built with glass windows and so the room had good light and sight. The roof of the room was made from chipped wood and well-ordered and more or less had no dirty spots and torn parts. I counted 48 students but was told that the class was serving 55 students: 22 boys and 33 girls.

I observed the class on the next day of the previous observation (on Tuesday morning, $4^{\text {th }}$ May, 2021). The class took place on $3^{\text {rd }}$ period from 10:10-11:05 am. And before I started my actual observation, it took me some minutes to have hard discussions and negotiations with the teacher. He was not willing to let me observe until after I convinced him that the observation had nothing to do with him and his job. I even tried to look for someone I knew, and luckily I got a friend to help me in convincing the regular teacher.

When I entered the room, all the students stood up and greeted the teacher and me warmly. We thanked them and then, I took one of the back corner seats. Soon, the teacher briefly informed the class the reason for my presence and told them to feel free.

This class started at 10:14a.m, it was not sharp time, but the teacher arrived after 4 minutes late. He, first, told the students that he was revising the last topic seen in the previous class, which was about using different forms of adjectives in a sentence. The teacher himself revised the topic writing some examples on the board. But, he did not give time to the students to think about the previous main points and share some points with their partners. He simply said that you learned and practised this very well in the previous class. He took nearly 5 minutes to complete the revision.

Next, he tried to introduce the day's reading lesson titled: 'Shamolo Returns Home'. He first, said, our today's lesson was reading. He even explained some points about the passage from his own mind. He also asked the students about whether they went away from their home or not, and the reasons why people went away from their home. The problem was that the teacher did not give the students think-time. So, during this part of the class, the students were in silence and 
apparently looking at the blackboard. As I could observe, this part of the class was completely teacher-centered, although it served as a pre-reading section. The teacher took about 5 minutes for this.

Then, the teacher told the students to open their book on page140. He wrote the title of the passage on the board. Then, he told them to listen to him while he was reading; especially his way of reading, his pronunciation, oral fluency and speed of reading. Accordingly, he read the passage out loud once. Next, he asked the students whether they were ready to read the passage in the same way. Seemingly, most students agreed. He told them to read individually very quickly. While students were 'reading', the teacher was standing in front of the class and appeared as if he was reading.

After a while, he told them to be quiet, and invited some students to read for the class. He randomly gave chance to two students to read to the class turn-by turn. During this time, there was no teacher interference. The students read the passage with frequent difficulties in pronouncing some words in the passage and again they struggled hard to keep a certain level of the pace of their reading. It was observed that the students were really suffering even to read some sentences appropriately in the process. There was even silence for some seconds in the middle of their reading. In particular, lack of the opportunity to be exposed to some key vocabulary before reading seemingly contributed to students' difficulty to read the text with ease.

Another quite surprising thing was that the students did not have any purpose in mind regarding why they were reading. They were exposed to no comprehension strategies. There were neither used the three phases of reading activities nor even informed. They were just asked to read first individually then listen to some 'good readers'. He took almost twenty-two minutes for this.

Then, he told students to have a look at the comprehension questions. He told them just to be in group and answer the questions. He gave them 8 minutes to answer comprehension questions of 7 items. After that he told them that he was going to read the questions and ask them to give answers by raising hands. He read the first question and asked students to answer. But, students became silent and did not make effort to answer. Some students were looking once at the passage or book and in other time each other, without answer. Then, the teacher himself gave answer to the first question and tried to inform them where he found the answer in the passage. 
Next, he asked the second question and some students raised their hands. He continued in the same way till the students answered all the questions. Finally, he tried to summarize the reading lesson. He asked them the main points they learned from the passage. However, most students were in silence. He finally revised the topic of the lesson and told them to do exercise 1 and 2 as homework. The only moment of more of students' participation was the moment of doing passage questions in a group, in which students had hot chatting. Later, the moment of teacher questioning and student answering was slightly the other time of student involvement in this lesson.

The crux of the matter was that students were not exposed to any strategic reading. There were no pre-reading, while-reading and post-reading activities. Again, there was no any comprehension strategy to be used during reading. They were simply told first to model the way teacher read, his pronunciation and fluency and second to follow how two of their classmates, presumably 'good readers' read the text. Then, they were told to be in group and answer passage questions.

The teacher took extra 5 minutes from the next time and the class ended at about 11:05.

After the class, I managed to have a sort of free discussion with the teacher on his general understanding of teaching reading comprehensions skills and on the specific method or procedures he often used in class. I audio-recorded his response and transcribed as follow:

In a reading lesson, I often first read a passage to my students loudly. Then, I assign some two or three students who are good at reading to read the passage out loud to the class. I tell the other students to listen to the reading and try to aspire to read like their friends. After reading, students do comprehension questions in a group of, for example, three or four. When they finish, I ask the class each question and give them chance to answer orally. If, for example, a student gives wrong answer, I ask the class whether they support the answer or not. If not, I ask for anyone who could give correct answer. There are also cases in which I ask my students to justify or show us where they get the answers by referring to the passage: paragraph and line number. Finally, I give correction if necessary. Anyway, teaching reading is not easy. 
Analysis of Focus Group Discussion Data

Research question one: What is reading comprehension skills for you?

Open codes for $R Q 1$

\begin{tabular}{|l|l|l|}
\hline \multicolumn{1}{|c|}{ Open code } & \multicolumn{1}{|c|}{ Properties } & \multicolumn{1}{c|}{ Examples of participants' Words } \\
\hline $\begin{array}{l}\text { Defining } \\
\text { comprehension }\end{array}$ & $\begin{array}{l}\text { - skill of understanding text } \\
\text {-Receiving text message }\end{array}$ & $\begin{array}{l}\text { W.. skill of understanding a given text } \\
\text { understanding; it is looking at receiving a text }\end{array}$ \\
\hline
\end{tabular}

Research question two: What are your main focuses in teaching reading comprehension skills in your class?

Open codes for $R Q 2$

\begin{tabular}{|l|l|l|}
\hline \multicolumn{1}{|c|}{ Open code } & \multicolumn{1}{|c|}{ Properties } & \multicolumn{1}{c|}{ Examples of participants Words } \\
\hline $\begin{array}{l}\text {-Traditional view; } \\
\text { textual accuracy }\end{array}$ & - Valuing text content, & $\begin{array}{l}\text { - trying to make students understand } \\
\text { what they are reading. } \\
\text { - helping learners to understand the } \\
\text { central meaning of a text. }\end{array}$ \\
& -Literal comprehension & $\begin{array}{l}\text { - grasping or understanding the central } \\
\text { point of the written material }\end{array}$ \\
\hline - Selective focus & -Discerning textual message \\
- focusing on text content & $\begin{array}{l}\text {-They are not expected to understand the } \\
\text { all material } \\
\text { - making sure students understand the } \\
\text { main points of the content of the text }\end{array}$ \\
\hline
\end{tabular}

Research question Three: How do you teach reading comprehension skills in your class?

Open codes for $R Q 3$

\begin{tabular}{|l|l|l|}
\hline \multicolumn{1}{|c|}{ Open code } & \multicolumn{1}{|c|}{ Properties } & \multicolumn{1}{c|}{ Examples of participants' Words } \\
\hline Methodology & $\begin{array}{l}\text { - using reading phases } \\
\text {-using background } \\
\text { experience }\end{array}$ & $\begin{array}{l}\text {-I teach [using] pre-reading, while- } \\
\text { reading and post-reading. } \\
\text { - ask them something related to the text } \\
\text { that they are going to see...their } \\
\text { background experience and others. }\end{array}$ \\
\hline
\end{tabular}




\begin{tabular}{|c|c|c|}
\hline Reading strategies & $\begin{array}{l}\text { - making use of } \\
\text { comprehension strategies }\end{array}$ & $\begin{array}{l}\text { - I am following different strategies, for } \\
\text { example, strategies such as skimming } \\
\text { and scanning } \\
\text { - understanding of the general ideas of } \\
\text { the reading text and the details of a } \\
\text { reading text }\end{array}$ \\
\hline
\end{tabular}

Research question Three: What types of comprehension strategies do you think improve students reading skills?

Open codes for $R Q 4$

\begin{tabular}{|c|c|c|}
\hline Open code & Properties & Examples of participants' Words \\
\hline $\begin{array}{l}\text {-Personal experience } \\
\& \text { preference }\end{array}$ & $\begin{array}{l}\text { - Bottom-up or text-based } \\
\text { approach } \\
\text {-Top-down approach or } \\
\text { schematic knowledge }\end{array}$ & $\begin{array}{l}\text { - For primary level students, } \\
\text { particularly, for students who do not } \\
\text { have better knowledge in reading. } \\
\text { - Students are required to focus on the } \\
\text { given text. } \\
\text { - Students are expected to bring their } \\
\text { background knowledge to the text }\end{array}$ \\
\hline Personal beliefs & $\begin{array}{l}\text { - Feeling of being role- } \\
\text { model } \\
\text { - Teacher focused oral } \\
\text { practice } \\
\text {-Personal treatment }\end{array}$ & $\begin{array}{l}\text { I read to show them how to read that } \\
\text { text } \\
\text {-students should respect that way I am } \\
\text { reading } \\
\text { - teachers should bring interesting story } \\
\text { to class to read }\end{array}$ \\
\hline Student-led reading & $\begin{array}{l}\text { Prioritizing general ideas } \\
\text { (Skimming) }\end{array}$ & $\begin{array}{l}\text { - First, we have to ask learners to read } \\
\text { the text. } \\
\text { To understand the general idea, this is a } \\
\text { strategic approach. } \\
\text {-Remember that reading is an individual } \\
\text { task not group work. } \\
\text {-I ask students to read individually to } \\
\text { understand the central idea of the text. }\end{array}$ \\
\hline
\end{tabular}




\begin{tabular}{|l|l|l|}
\hline $\begin{array}{l}\text { personal reading } \\
\text { strategies }\end{array}$ & $\begin{array}{l}\text {-Using silent and loud } \\
\text { reading }\end{array}$ & $\begin{array}{l}\text {-There are two types of strategies, } \\
\text { concerning students reading. One they } \\
\text { read silently: silent reading by } \\
\text { themselves. }\end{array}$ \\
-Secondly, loud reading by themselves
\end{tabular}

Research question five: How is it possible to help students develop independent or selfregulated reading skills?

Open codes for $R Q 5$

\begin{tabular}{|c|c|c|}
\hline Open code & Properties & Examples of participants' Words \\
\hline $\begin{array}{l}\text { Setting reading } \\
\text { purpose }\end{array}$ & $\begin{array}{l}\text {-mind-purpose for reading } \\
\text { - purpose facilitates } \\
\text { understanding }\end{array}$ & $\begin{array}{l}\text { - before students engage in reading, we } \\
\text { have to tell them the purpose for } \\
\text { reading. } \\
\text { - If they know why they are reading, } \\
\text { they will engage in the text and they will } \\
\text { use their time to understand the entire } \\
\text { text }\end{array}$ \\
\hline $\begin{array}{l}\text { Provision of extra } \\
\text { text }\end{array}$ & $\begin{array}{l}\text {-Exposing to authentic } \\
\text { reading text } \\
\text { - Encouraging inclusive } \\
\text { reading }\end{array}$ & $\begin{array}{l}\text {-...bringing authentic reading text to } \\
\text { them } \\
\text {-....giving chance to all students to read. }\end{array}$ \\
\hline Affective factors & $\begin{array}{l}\text {-motivating independent } \\
\text { reading } \\
\text {-orienting purpose for } \\
\text { reading }\end{array}$ & $\begin{array}{l}\text { - motivating them to reading wherever } \\
\text { possible } \\
\text { - telling them the purpose or advantage } \\
\text { of independent reading. }\end{array}$ \\
\hline Shared reading & $\begin{array}{l}\text {-Jigsaw approach } \\
\text { - Encouraging group reading }\end{array}$ & $\begin{array}{l}\text { - It is advisable to divide students into } \\
\text { small groups. }\end{array}$ \\
\hline Extensive reading & $\begin{array}{l}\text {-Giving home reading } \\
\text { _encouraging self-reflection } \\
\text { or report or personal reading }\end{array}$ & $\begin{array}{l}\text { - You have to give students home } \\
\text { reading tasks. } \\
\text { - Next time, you ask them general } \\
\text { questions to check their reading and to } \\
\text { reflect to the class. } \\
\text { - making students to read outside and } \\
\text { come to the next class. }\end{array}$ \\
\hline
\end{tabular}


Research question six: What are your major roles as a teacher when you teach reading skills in your class? What are your specific activities?

Open codes for RQ6

\begin{tabular}{|c|c|c|}
\hline Open code & Properties & Examples of participants' Words \\
\hline $\begin{array}{l}\text {-Using teaching } \\
\text { aids }\end{array}$ & $\begin{array}{l}\text { Preparing visual aids, flash } \\
\text { cards }\end{array}$ & $\begin{array}{l}\text {-using flash cards, some visual aids that } \\
\text { you use. And then, also make students } \\
\text { look at the pictures and match. }\end{array}$ \\
\hline \multirow[t]{2}{*}{ Teachers' Roles } & $\begin{array}{l}\text { - Acting as facilitator, } \\
\text { motivator } \\
\text {-Helper, giving help while } \\
\text { students in difficulty } \\
\text { Monitoring, directing } \\
\text { students (giving instruction) }\end{array}$ & $\begin{array}{l}\text { - Teacher should be facilitator and } \\
\text { motivators while students reading. } \\
\text { - If our students get something difficult, } \\
\text { we have to help them. } \\
\text { - I just move round the class and monitor } \\
\text { the class. }\end{array}$ \\
\hline & $\begin{array}{l}\text {-Creating conducive learning } \\
\text { environment } \\
\text {-Providing extra reading text } \\
\text { Assessing students' progress }\end{array}$ & $\begin{array}{l}\text {-I have to create a conducive environment } \\
\text { for the learners to read the entire text. } \\
\text { - We have to bring as a teacher materials } \\
\text { that go with their interest and their level. } \\
\text { - The other role of the teacher is } \\
\text { controlling the progress. } \\
\text {-How they progress in the first semester, } \\
\text { second semester and what is their final } \\
\text { progress are another role of the teacher. }\end{array}$ \\
\hline
\end{tabular}

Research question seven: What are the students' major roles or major activities in a reading class? What do they do; how do they learn? What are their responsibilities in the reading class?

Open codes for $R Q 7$

\begin{tabular}{|c|c|c|}
\hline Open code & Properties & Examples of participants' Words \\
\hline Students' Roles & $\begin{array}{l}\text {-Active participation } \\
\text {-Being responsible }\end{array}$ & $\begin{array}{l}\text {-they are really expected to take part } \\
\text { actively in the reading session. } \\
\text { - When questioning and answering, they } \\
\text { are required to question the teacher }\end{array}$ \\
\hline
\end{tabular}


Research question eight: What do you think is the general culture of teaching reading comprehension at primary schools? Is there uniformity among us, teachers? Or what have you learned from your lived experiences since you have been in the profession for long years?

Open codes for $R Q 8$

\begin{tabular}{|c|c|c|}
\hline Open code & Properties & Examples of participants' Words \\
\hline $\begin{array}{l}\text { Challenges in } \\
\text { teaching reading }\end{array}$ & $\begin{array}{l}\text { - Lack of firsthand } \\
\text { exposure to reading, } \\
\text { - teachers' failure to } \\
\text { motivate students } \\
\text { - Absence of } \\
\text { supplementary reading } \\
\text { texts } \\
\\
\text {-Lessening students' } \\
\text { learning capacity; } \\
\text { degrading students' } \\
\text { learning ability } \\
\text { - Uninviting culture of } \\
\text { teaching } \\
\text {-inconvenient learning } \\
\text { environment } \\
\text { - Culture of teaching } \\
\text { reading } \\
\text { - Mismatch between } \\
\text { principles of reading } \\
\text { and the actual teaching } \\
\text {-Being irresponsible } \\
\text { and textbook-oriented }\end{array}$ & $\begin{array}{l}\text { - Students do not get firsthand exposure to } \\
\text { reading. } \\
\text { - Teachers are not motivating students to read. } \\
\text { - Teachers are not bringing interesting reading } \\
\text { texts to the class. } \\
\text { - --- teachers think that students are } \\
\text { elementary and simply enter class for the sake } \\
\text { of learning, but not to reading. } \\
\text { - The culture of teaching reading does not } \\
\text { reinforce students to learn reading. } \\
\text { - The environment does not create reading } \\
\text { opportunity, and so it is impossible to bring } \\
\text { real reading practices to the classroom. } \\
\text { - We do not have good culture to teach } \\
\text { reading. } \\
\text { - There is a gap between the principles of } \\
\text { reading and the actual teaching of reading. } \\
\text { - What teachers do in the classroom, especially } \\
\text { in the reading classroom, they make the } \\
\text { learners to read the text for the sake of } \\
\text { covering the passage, } \\
\text { - What teachers do in the classroom is just } \\
\text { asking learners to cover the text. }\end{array}$ \\
\hline $\begin{array}{l}\text { - Prevalence of } \\
\text { poor reading } \\
\text { habits }\end{array}$ & $\begin{array}{l}\text { - Family failure to } \\
\text { develop the culture of } \\
\text { early age reading } \\
\text { - School failure to } \\
\text { establish reading } \\
\text { culture, corners... }\end{array}$ & $\begin{array}{l}\text {---- reasons for the poor reading habits in } \\
\text { Ethiopian context are one family. } \\
\text { - When we go to---Western Countries, they } \\
\text { have time for reading starting from child age. } \\
\text { - Coming to the school, the same thing } \\
\text { happens in schools because we don't have the } \\
\text { culture. }\end{array}$ \\
\hline
\end{tabular}




\section{Selective codes and substantiate codes based on the open codes}

\begin{tabular}{|l|l|l|}
\hline \multicolumn{1}{|c|}{ Open codes } & \multicolumn{1}{|c|}{ Selective codes } & \multicolumn{1}{c|}{ Substantiate codes } \\
\hline Defining comprehension skills & Ability of comprehending & $\begin{array}{l}\text { Regarding as } \\
\text { cognitive skills }\end{array}$ \\
\hline $\begin{array}{l}\text { Traditional view; textual accuracy; } \\
\text { selective focus; student-led reading; } \\
\text { setting reading purpose; shared } \\
\text { reading; using teaching aids }\end{array}$ & $\begin{array}{l}\text { Focusing on textual } \\
\text { information }\end{array}$ & $\begin{array}{l}\text { Practice of more of } \\
\text { bottom-up or text- } \\
\text { based approach }\end{array}$ \\
\hline $\begin{array}{l}\text { methodology; reading strategies; } \\
\text { personal experience \& preference; } \\
\text { subjective reading strategies; provision } \\
\text { of extra texts }\end{array}$ & $\begin{array}{l}\text { incidental and } \\
\text { teaching }\end{array}$ & $\begin{array}{l}\text { Intuitive or } \\
\text { spontaneous teaching } \\
\text { approach }\end{array}$ \\
\hline $\begin{array}{l}\text { - Personal beliefs; affective factors; } \\
\text { teachers' roles; students' roles }\end{array}$ & $\begin{array}{l}\text { Desiring for shared } \\
\text { teaching-learning roles }\end{array}$ & $\begin{array}{l}\text { Wanting shared } \\
\text { responsibility and } \\
\text { learning roles }\end{array}$ \\
\hline $\begin{array}{l}\text { - Challenges in teaching reading; } \\
\text { prevalence of poor reading habits }\end{array}$ & $\begin{array}{l}\text { Demand school-family } \\
\text { sharesponsibility }\end{array}$ & $\begin{array}{l}\text { Wanting school-family } \\
\text { attachment }\end{array}$ \\
\hline
\end{tabular}

\section{Discussions and Interpretations of Findings}

The classroom observation results revealed that there was no real attempt to employ various comprehension strategies to improve students' reading skills. The existing literature presents research proven comprehension strategies but the actual teaching reflected very arbitrary and personal approaches to teaching reading skills. Students simply struggle to model their teachers' pronunciation and reading fluency, and try to comprehend anything possible when they read.

It means there were no strategic approaches to help students develop the skills for comprehending a text they read. Besides, this study reflected the wide gap between what empirical researches provided as effective comprehension strategies to improve students' reading 
comprehension skills and the practical trend of teaching reading at elementary schools. Once more, research confirmed comprehension monitoring techniques: pre-reading, while-reading and post-reading activities were seemingly replaced by teacher modeling oral reading followed by targeted individual reading and group reading practices.

However, different scholars and researchers have repeatedly validated the role of reading comprehension strategies in improving students' thinking and reading skills for a long time. In 1978, for example, Klinger and Van Dijk, cited in Santa (2000), documented that a reader makes sense of the organization and flow of ideas in a text using interpretive interactions between what he or she already knows and what is given in a text. They theorized that a reader constructs meaning as 'mental representation' and stores the text messages in his or her memory as 'semantic representations' during reading.

Likewise, a research conducted by Ann B. \& L. Friedman, T. (2020), identifies certain strategies which are very important to improve students' reading thinking and comprehension skills; these comprehension monitoring skills include activating prior knowledge, predicting, generating questions, using graphic organizers and summarizing. They further note that using researchproved strategies improve not only students' ability to read a text and comprehend text message, but also cultivate their ability to critical thinking and analyze unstated information.

In particular, it would sound that children need explicit instruction in vocabulary during prereading stage. They need to learn some key vocabularies that could facilitate reading. However, the classroom observation results indicated no teacher attempts to teach key vocabulary in the reading lessons. Similarly, the result of the FGD magnified that explicit teaching of some key vocabulary taken from a reading passage before students start reading was totally neglected. Yet different research findings indicate that teaching key vocabulary plays a constructive role in helping children learn to read (Block, Gambell \& Pressley, 2002; Roskos \& Neuman, 2014).

Results show that students often practice reading lessons to get the knowledge of facts as stated in the reading texts. Nonetheless, many scholars and researchers argue that reading practices which focus on text information (or textual message), limit students' thinking skills to the lowest cognitive level (King, Goodson \& Rohani, 1998; Anderson, \& Krathwohl, 2001; Tankersley, 2005; McNamara, 2007; Brookhart, 2010). That is to say, in one sense, the comprehension questions demand students to focus on lower-order thinking skills or just recall or reading for 
factual responses, In another sense, the comprehension instructions which require higher-order thinking skills like activating prior knowledge, predicting, reading with purpose, visualizing, evaluating, making connection between text message and own actual situations, retelling or summarizing are left aside. Thus, there a is an pressing need to shift the practice of teaching reading from comprehension-based focus to thought- based approach.

The FGD report revealed wide irregularities among teachers in teaching reading comprehension skills. Some favour teacher modeling reading fluency, like pronunciation and speed of reading, while others stress the importance of using different reading activities (pre-reading, whilereading and post-reading activities). This also included using comprehension strategies like scanning for details and skimming for the central idea of a text. Yet, what was quite surprising were that almost all participants in this research be in the classroom observation or in the FGD, had little knowledge of the existence of various comprehension strategies.

A report of the experts on early grade reading in Ontario (2013), for example, points out that "Comprehension is the ability to understand, reflect on and learn from text. To ensure that children develop comprehension skills, effective reading instruction builds on their prior knowledge and experience, language skills, and higher-level thinking” (p. 13). As the report states, some of the strategies children should learn with fluency and better comprehension include reviewing prior knowledge and experience, metacognition and higher thinking skills.

Likewise, the result of the open, selective and substantiate coding confirm that the frequently practised trend of teaching reading was more of reading out loud with special focus on oral accuracy and fluency. Students were not only demanded to model their teachers' way of reading in terms of pronunciation and speed of reading, but also required to read for textual information at the expense of developing metacognitive skills. As to the result, the most common constraints of teaching reading become more of pragmatic constraints including students' low reading competence, adherence to factual or literal comprehension, teacher-fronted reading practice, teachers' lack of metacognitive and comprehension monitoring strategies, and the mismatch between teachers' own teaching preference and the existing empirical research findings.

The findings also unveil that teachers were highly likely to establish their own culture of teaching reading skills at primary schools, and this could show the gap between what is recommended in literature and what is going on in practice in the actual classrooms. What is 
more, findings reveal that the teaching of reading at primary school focus more on text-based comprehension with little or no attention to thinking or thought-based reading processing.

On the other hand, the FGD data analysis revealed that the teachers had some awareness of comprehension monitoring strategies (the use of pre-reading, while-reading and post-reading activities) to facilitate comprehensions, whereas the classroom observation result indicated no use of the strategic reading approaches. Again, as to the FGD results, teachers were reportedly less committed and motivated to help students connect their prior knowledge to the content of the reading text in order to develop new knowledge. The results of FGD analysis also shows that the present trend of teaching reading contributes less to help students develop independent reading skills. As to the results of the classroom observation, students were encouraged to focus more on getting text information as stated in the passages to only answer passage questions.

\section{Conclusions}

The results of the FGD analysis confirm that teachers had little knowledge and experience of using specific thinking and comprehension strategies. Similarly, the results of the classroom observation indicated that teachers were not using the strategic reading processes (pre-reading, while-reading and post-reading activities and the comprehension strategies.

The results of the classroom observations and FGD analysis show that there appeared to be little difference in the underlying pedagogy of teaching reading comprehension skills among the teachers at the primary schools in focus. The more regularly practised approach of teaching reading skills tended to focus on improving students' oral reading accuracy and comprehension of textual message mainly to answer passage questions. The after classroom observation discussion also suggested there was little focus on developing students' thinking skills in the process of reading.

The crux of the matter was that students spent a great deal of time on listening and trying to answer comprehension questions which demanded them more of reading for surface meaning. And this might contribute little to develop students' cognitive and beyond textual understanding skills. As the result of the analysis shows the most common challenges to promote students' comprehension and higher thinking skills are, among others, more of pragmatic constraints including teachers trends of teaching such as adherence to factual or literal comprehension, 
teacher-fronted reading practice, teachers' lack of metacognitive and comprehension monitoring strategies, and the mismatch between teachers' own teaching preference and the existing empirical research findings.

Thus, it could be concluded that the trend of teaching reading comprehension skills at primary schools become more of arbitrary and intuitive in its approach. The classroom reading practices appeared to contribute less to develop students thinking and comprehension skills. Students got little opportunity to practise comprehension monitoring strategies through which they experience strategic reading ability. They also lack the opportunity to be exposed to explicit teacher-led comprehension strategy practices which students are gradually expected to take over the responsibility to use the strategies for their own lifelong learning.

Overall, the study findings show the need for primary school teachers to shift their pedagogic reading practices from the use of teacher-led oral practices and instructions to address the narrow choice of teaching reading practices to research-proven thinking and comprehension strategies. There is timely demand to change the focus of reading instructions from a set of comprehensionbased reading activities (such as: pre-, while- and post comprehension-based reading activities) to a set of thought-based comprehension strategies that students practise at the three stages of the reading processes. In other words, the focus of teaching reading should be teaching children how to think instead of what to think.

\section{Recommendations}

Based on the research findings, the following are suggested as critical issues to be considered.

1. It was found that equipping teachers' with the necessary metacognitive, cognitive and comprehension monitoring strategies have been identified as a critical area of concern and key for improving students' reading comprehension skills. The belief is that a motivated and well--trained teaching force is a prerequisite for improving children's reading comprehension and higher order thinking skills. Thus, it is highly recommended that the ministry of education in collaboration with teacher training institutions should set a way to reform the quality of pedagogical instructions, strategies and the trends of teachers' trainings.

2. It is recommended that teachers need to be provided continuous well-organized in-service trainings, seminars or workshops on how to use strategic reading approaches and different 
comprehensions strategies in the process of reading to improve students' thinking and comprehension skills.

3. Curriculum developers, syllabus designers and English language experts as well as textbook writers are primarily responsible for preparing reading tasks which build up students' thinking and reading strategies. Thus, the concerned bodies in developing English curriculum and textbooks need to focus on instructions and learning activities that build up students' competences and higher-level thinking strategies, especially by limiting those activities and tasks which focus on lower-order thinking skills.

\section{References}

Anderson, N. J. 1991. "Individual Differences in Strategy Use in Second Language Reading and Testing." Modern Language Journal, 75(4), 460-472.

Anderson, L. W., \& Krathwohl, D. R. 2001. A Taxonomy for Learning, Teaching, and Assessing: A Revision of Bloom's Taxonomy of Educational Objectives. New York: Longman.

Ann B. \& L. Friedman, T. 2020. "Interventions for Eighth Graders": Adolescent Literacy Resources for Parents and Educators of Kids in Grades 4-12. New York: AdLit.org.

Block, C., Gambell, L. \& Pressley, M. 2002. Improving Comprehension Instructions, Rethinking Research, Theory and Classroom Practice. San Francisco: Jossey-Bass.

Block, C. and Israel, S. 2005. Reading First and Beyond. The Complete Guide for Teachers and Literacy Coachers. Thousand Oaks, CA: Corwin Press.

Brookhart, S. M. 2010. How to Assessing Higher Order Thinking Skills in Your Classroom. USA: ASCD

Durkin, D. 1978-1979. "What Classroom Observations Reveal about Reading Comprehension." Reading Research Quarterly. 15, 481-533.

Federal Democratic Republic of Ethiopia Ministry of Education. 2016. Early Grade Reading Interventions in Ethiopia. Developing Quality Books and Ensuring Access. International Literacy Day, Washington, DC, USA

Gill, S. 2008. "The Comprehension Matrix: A Tool for designing Comprehension Instruction." The Reading Teachers, 62(2), pp. 106-113.

King, E. J., Goodson, L. \& Rohani, E. 1998. Higher Order Thinking Skills: Definitions, Teaching Strategies and Assessment. USA: Florida State University.

McCormac, M. 2012. Literacy and Educational Quality Improvement in Ethiopia. A Mixed Methods Study. A Dissertation submitted to the University of Maryland, College Park. 
Mcknown, B. A. \& Barnett, C. L. 2007. Improving Reading Comprehension through Higher Order Thinking Skills. Chicago, Illinois: Saint Xavier University.

McNamara, Danielle S. 2007. Reading Comprehension strategies: Theories, Interventions and Technologies. USA: Lawrence Erlbaum Associates, Inc.

NSW Department of Education and Training Literacy Continuum. 2010. Teaching Comprehension Strategies. USA: NSW Government.

Ontario Ministry of Education. 2003. Early Reading Strategy. The Report of the Expert Panel on Early Reading in Ontario. Toronto: Cette Publication.

Palincsar, A. \& Brown, A. L. 1984. "Reciprocal Teaching of Comprehension-Fostering and Comprehension-Monitoring Activities.” Cognition and Instruction. 1, 117-175.

Pearson, P. D. \& Gallagher, M. C. 1983. "The Instruction of Reading Comprehension." Contemporary Educational Psychology. 8, 317-344.

Pressley, M. et al. 1991. "Strategy Instruction at Benchmark School: A Faculty Interview Study." Learning Disabilities Quarterly, 14, 19-48.

Rand Reading and Study Group. 2002. Reading for Understanding: Toward an $R$ \& D Program in Reading Comprehension. Santa Monica, CA: RAND.

Roskos K. \& Neuman. S. B. 2014. "Best Practices in Reading: A 21st Century Skill Update." The Reading Teacher, 67(7), 507-511.

Santa, Carol Minnick. 2000. "The Complexity of Comprehension: Effective Comprehension Instructions Requires Extensive Teacher Knowledge." Reading Today, International Reading association.

Smith, C., Stone, R. \& Comings, J. 2012. Field Study Report, Literacy Policy and Practice in Ethiopia: American Institute for Research (AIR) under the USAID EQUIPI TELL Program. University of Massachusetts Amherst, MA

Solomon Abera. 2014. Status and Determinants to Reading Skill Development. A Thesis submitted to Institute of Educational Research. AAU

Tankersley, Karen. 2005. Literacy Strategies for Grades 4-12: Reinforcing Threads of Reading. USA: ASCD.

Tierney, R. J. and Cunningham, J. W. 1984."Research on Teaching Reading Comprehension.” In Handbook of Reading Research. New York: Longman.

Van de Broek, P. et al. 2009. Reading Between Lines: Developmental and Cognitive Processes in Reading Comprehension.

Yang, G. 2001. “The Relationship between Reader's Beliefs and Reading Strategies. Unpublished PhD Dissertation. State University of New York. 